\title{
Evaluation of Investment Attractiveness and Prediction of Investment Volumes to the Region
}

\author{
Liliya Sabikhovna Valinurova ${ }^{1}$ \\ Oxsana Borisovna Kazakova1
}

Elena Alexandrovna Sulimova ${ }^{2}$

\author{
${ }^{1}$ Bashkir State University, Russia, 450076, Ufa, Zaki Validi Street, 32 \\ ${ }^{2}$ Russian University of Economics G.V. Plekhanov, Russia, 117997, Moscow, Ctremyanny lane, 36
}

Doi:10.5901/mjss.2015.v6n5s3p371

\begin{abstract}
In the given research there has been suggested the approach to the evaluation of the investment attractiveness of the regions of Privolzhsky Federal District, and outlined the key factors of its fluctuation in particular regions. There has been developed the model of investments volumes reliance on investment attractiveness of the region, specified tendencies/trends of the change of investment flow to the regions of Privolzhsky Federal District until 2020. The analysis shows that the use of standard forecasting procedures allows to obtain results of high quality. Thus there is a need to improve the algorithm for determining and predicting the perturbations of the investment process which will improve the accuracy of calculations, and identifying criteria for optimal growth of the investments to ensure the effective functioning of the economic system.
\end{abstract}

Keywords: investment processes, investment attractiveness, assessment of investment attractiveness, forecasting investments inflow, regional development.

\section{Introduction}

The present stage of the development of international economics (world economy) is characterized by the development of new forms of integration of business entities and the formation of corporate structures, focused on technical reequipment and production growth. Intensification of innovative processes in all sectors of the economy determines the need for investment support emerging between countries and regions with stable economic ties.

Attracting investments is one of the conditions for steady development of the economy of the region. That is why serious attention is being paid to the formation of favorable investment climate both in Privolzhsky Federal District and in its separate regions. Investment attractiveness is considered as an integrated indicator of favored nation basis for an investor.

Taking into consideration that the management of any process should be based on unbiased assessments of the state of its flow, the need to assess the investment attractiveness of regions becomes apparent.

Since the issue of managerial decision-making requires not just affirmation of some actions taken but, above all, achieving goals, the issue of evaluation of investment attractiveness goes into the quantitative measurement of this index and identification of the areas to be improved.

One of the undoubted reserves of economic growth is the improvement of the investment process and an increase of investment volume in the real sector of the economy. Despite some positive developments in the investment sphere, there hasn't been seen the expected growth of the investment activity.

In the conditions of innovative economy and active integration development it is particularly important to develop the effective management of investment processes, including the set of activities aiming them at the achievement of maximum growth of socio-economic system, and consisting of the following set of actions:

1) the analysis of the current state of the investment process including: investment attractiveness analysis, investment activity; the analysis of meeting the needs of the socio-economic system in the;

2) calculation of the required volume of investments and evaluation of the investment attractiveness, corresponding to this volume;

3) development, selection and implementation of measures allowing to reach the required state of investment attractiveness of the socio-economic system; 
4) the change of the investments inflow in the socio-economic system, caused by the improvement of investment attractiveness;

5) changing the parameters of socio-economic development of countries and regions financed from investments, lying in the pace of economic growth.

Constant implementation of the cycle determines the continuous improvement of the system of the investment process management and improving the efficiency of innovative development of socio-economic systems.

Under such conditions the issues of the investment process management become more and more important. The approach based on the prediction of capital forming investments inflow into economic and social systems becomes of particular importance.

\section{Recent Research and Publications Analysis}

The works of many academic economists are devoted to the study of effective tools of management of investment processes at the regional level, based on the formation of investment attractiveness of the area: V.V. Livinova, S.Filin, A.N. Goncharov, D.I. Ryakhovskiy, V.N. Myakshin and others. In this connection investment ratings and ratings of investment attractiveness of regions obtained a wide circulation; these are assigned by such rating agencies as "Expert RA", "National Rating Agency", "Agency of Strategic Initiatives on New Projects Promotion Agency" etc.

International organizations when considering loan applications rely on the ratings of investment attractiveness and creditability provided by the agencies as Standard \& Poor's, «Moody's», Fitch IBCA и Thompson Bankwatch.

The analysis of the currently available models used in the investment management, allows to draw the following conclusions (L.S. Valinurova, O.B. Kazakova, 2005, L.P. Goncharenko,S.A. Filin, A.G. Yakushev, V.F. Akulinin, 2013, A.N. Goncharov, 2012, V.A. Kardash, 1998, V.V. Litvinova, 2013, V.N. Myakshin,2014, D.I. Ryakhovskiy, N.G. Akulova, A.V. Balabanov, 2014):

1) most of them are focused on individual projects and enterprises; and consider the investment process only on the part of an investor;

2) certain factors used in the models are difficult to assess or it's impossible to obtain their quantitative characteristics;

3) in many models there are used projected values of factor indicators, while the method of their evaluation is not described.

\section{The Research Objectives}

Taking into account the best practices in the field of management of investment processes and the requirements in modern economy, the main objective of this research is to develop a model of investment processes management corresponding to the following requirements:

- application of the investment attractiveness index, the change of the latter allows to control the invest capital;

- compliance with the principles of consistency, reliability, ease of use;

- $\quad$ having the property of transformation (easy to adapt);

- consideration of environment factors and the behavior of the region in the future;

- $\quad$ the possibility of applying the scenario method of when using the model.

Key research findings.

\subsection{Methodological approach to the evaluation of investment attractiveness of regions}

Considering the features of the investment process and the results of the analysis of the investment situation in Russia there has been worked out the system of factors influencing the investment attractiveness of regions. The selection of factors was based on the principles of sufficient diversity, minimum significant sufficiency and target orientation. On this basis, the following factors have been identified: political, resource-based, industrial, consumer-oriented, infrastructural, investment, environmental (ecological), macroeconomic, financial, personnel, social and innovative.

Finding and studying the effects of absolutely all factors is really hard and not always rational. The challenge is in determination of the most significant factors determinative of economy behavior. Numerical characteristic of particular aspects of the analyzed phenomenon and process is expressed through the system of indicators. Changes in meanings of the factors are defined by impacts of one or several indicators. That's why the influences of some or other indicators on the investment attractiveness of economic and social systems are measured through the study of particular indicator group reflecting the effects of the given factors.

Based on the results of the analysis of different approaches to the assessment of investment attractiveness, there 
has been worked out and suggested the approach, based on the definition of economic and risk-related components of the regional investment attractiveness:

1) Economic - covers the level of return of invest funds;

2) Risk-related - characterizes the overall risk connected with the considered economic and social system.

According to the system of national accounts at the macro level as an indicator of income (economic component of investment attractiveness) the gross domestic product can be used (hereinafter GDP), obtained from the use of investments because this is the sum of the added values created in the sectors of economy throughout the year in monetary form (for a region - gross regional product as a set of added values of the branches of economy and net taxes on products).

Economy gross profit represents the part of added value which is kept by producers after subtraction of expenditures connected with compensation of employees and taxes on production and import. When calculating the economic component of the regional investment attractiveness, Gross Regional Product (GRP) has to be reduced by the amounts of budgetary deficit, compensation of employees and taxes on production and imports.

Risk component is needed to determine the overall risk characterizing the given economic and social system. Risk component of the investment attractiveness is cumulative in nature because it formed from joint impact of different specific factors and can be given as follows:

$$
k_{2}=\frac{\sum_{i=1}^{n} P_{i}{ }^{*} j_{i}}{\sum_{i=1}^{n} j_{i}}
$$

where: $k_{2}$ - risk component of investment attractiveness of the region;

$n$ - number of factors;

$P_{i}-$ characteristics of a factor;

$j_{i}-$ weighting coefficient of a factor.

The risk component helps to define what part of income will be lost as a result of its appearance. That's why the composite indicator of the investment attractiveness of a region can be presented as follows:

$$
k=k_{1} *\left(1-k_{2}\right)
$$

where $k$ - an economic and social system investment attractiveness factor, in unit fraction;

$k_{1}-$ an economic component of investment attractiveness, in unit fraction;

$k_{2}-$ a risk component of investment attractiveness, in unit fraction.

Investment attractiveness factor reflects economic effectiveness of investments and it is therefore necessary to be aware that, in accordance with international standards, depending on profitability, economic and social systems can be divided into 5 groups:

A - is characterized by high profitability, exceeding the average number fourfold and more;

B - with profitability above average, exceeding it twofold and more;

C - with average profitability 10-12 \%;

D - with profitability twice as little below average;

E - with very low profitability, more than twofold less below average.

Depending on the meaning of the factor of the investment attractiveness, the regions can be classified in the following order (table 1).

Table 1 - Classification of regions according to the investment attractiveness

\section{Characteristics of regions}

1. Regions with high investment attractiveness. Economics is resistant to crisis, diversified structure of

production, well-developed infrastructure, sound legislation, and qualified workforce capacity. Relatively friendly

ecological and criminogenic environment.

Regions with investment attractiveness above average - high level of production, allowable variations are determined by socio political factors.

Regions with average investment attractiveness. These are raw materials regions, well-being of which depend

on export and are greatly influenced by world market conjuncture.

Regions with investment attractiveness below average. These are regions with formerly high production level

but at present their well-being depends on state support.

Regions with low investment attractiveness (rather unfavorable investment climate). Even state support can't

guarantee healthy economic activity in such regions.

Indicator value (K)

$$
>0.4
$$

$0.1-0.2$

0.05-0.1

$<0.05$ 


\subsection{Methodological approach to the prediction of the volume of investments at the regional level}

Management of the investment process is based on the development of activities aimed at achieving the required volume of investments in the region. For the development of activities aimed at accomplishing this goal, it is necessary initially to determine the sphere and volumes of influence, and therefore the need to establish the difference between the required and expected volumes of investments.

In order to determine the expected amount of investments it is advisable to use the standard procedure of forecasting, since they allow to obtain the most accurate result with a fairly simple mathematical apparatus. It has to be taken into account that the forecast is performed in advance (ahead of schedule), therefore, the data needs to be adjusted after each prediction phase. In the proposed model an annual anticipatory interval is accepted, so the maximum accuracy of forecasts requires annual adjustment of the model parameters.

Taking into account the response time of socio-economic systems by values of the autocorrelation and cross correlation functions there have been defined the periods of delay of the investment attractiveness indicator impact on investment volumes. When modeling the type of relation between the volume of investment and investment attractiveness, there have been used the following parameters:

- Indicator of investment attractiveness of the region in the period t-1 $\left(K_{t-1}\right)$;

- Volume of investments in the region in the period $t-1\left(l_{t-1}\right)$;

- Factor of disturbances $(\lambda)$, allowing to take into account possible disturbances of the economic process (estimated/calculated on the basis of Theil-Wage model).

The employment of forecasting approaches allowed to find that in general terms the model will look as follows:

$I_{t}=f\left(I_{t-1}, k_{t-1}, \lambda\right)$

For the selection of the type of dependency there was used the technique of least squares, in particular, its modified form - method of characteristics of growths (V.A. Kardash, 1998).

Statistical characteristics of the models to predict the investment volumes show that it is efficient to apply dependence, which has the form:

$$
I_{t}=\frac{\left[a_{1} \times K_{t-1}+\ln \left(a_{2} \times I_{t-1}\right)\right]^{3,5}}{a_{3} \times \lambda}
$$

where $a_{1}, a_{2}, a_{3}-$ coefficients.

Based upon the analysis of the Privolzhsky Federal District (Russian Statistical Yearbook, 2013) and its 14 regions carried out for the period of 37 years (from 1975 to 2012) there have been evaluated (calculated) the values of the coefficients, each group of regions with their own values.

Based on the suggested approaches there has been developed a computer program " Evaluation of investment attractiveness and prediction of investment volumes to the region, 2014" (L.S. Valinurova, O.B. Kazakova, 2014).

\subsection{Evaluation of investment attractiveness of the regions of the Privolzhskiy Federal district.}

The approbation of the suggested approach to the assessment of investment attractiveness was carried out on the information arrays of 14 regions of the Privolzhsky Federal district (Russian Statistical Yearbook, 2013) using the author's software (Evaluation of investment attractiveness and prediction of investment volumes to the region, 2014) (tables 2, 3, 4).

Table 2 - Value of economic component of investment attractiveness of the Privolzhsky Federal District regions *

\begin{tabular}{|l|c|c|c|c|c|c|c|c|c|}
\hline & 2000 & 2005 & 2006 & 2007 & 2008 & 2009 & 2010 & 2011 & 2012 \\
The Republic of Bashkortostan & 0.2283 & 0.3138 & 0.3218 & 0.1732 & 0.2100 & 0.1676 & 0,2221 & 0.2379 & 0.2754 \\
The Republic of Marij El & 0.0636 & 0.2865 & 0.2938 & 0.2347 & 0.1368 & 0.1638 & 0,1984 & 0.2220 & 0.2265 \\
& 2000 & 2005 & 2006 & 2007 & 2008 & 2009 & 2010 & 2011 & 2012 \\
The Republic of Mordovia & 0.0699 & 0.1944 & 0.1994 & 0.2141 & 0.1365 & 0.1215 & 0,1348 & 0.1691 & 0.2035 \\
The Republic of Tatarstan & 0.2275 & 0.1896 & 0.1944 & 0.2075 & 0.1729 & 0.1501 & 0,2069 & 0.3035 & 0.3264 \\
The Udmurtian Republic & 0.1079 & 0.1984 & 0.2034 & 0.2616 & 0.1851 & 0.1213 & 0,2072 & 0.1988 & 0.2016 \\
The Chuvashi Republic & 0.0921 & 0.2623 & 0.2690 & 0.2576 & 0.1825 & 0.1300 & 0,1128 & 0.2051 & 0.2056 \\
The Perm Territory & 0.2082 & 0.2134 & 0.2188 & 0.2739 & 0.2327 & 0.1432 & 0,2200 & 0.2200 & 0.2351 \\
The Kirov Region & 0.0913 & 0.2165 & 0.2220 & 0.1920 & 0.1940 & 0.1244 & 0,2023 & 0.1945 & 0.1857 \\
The Nizhni Novgorod Region & 0.2651 & 0.2540 & 0.2605 & 0.2394 & 0.1908 & 0.1724 & 0,1578 & 0.2153 & 0.2631 \\
\hline
\end{tabular}




\begin{tabular}{|l|l|l|l|l|l|l|l|l|l|}
\hline The Orenburg Region & 0.2357 & 0.4810 & 0.4933 & 0.2828 & 0.1619 & 0.1527 & 0,1458 & 0.2902 & 0.2897 \\
The Penza Region & 0.0923 & 0.1975 & 0.2025 & 0.2618 & 0.1437 & 0.1126 & 0,0992 & 0.1719 & 0.1785 \\
The Samara Region & 0.3068 & 0.2742 & 0.2812 & 0.2416 & 0.1834 & 0.1777 & 0,2449 & 0.2370 & 0.2977 \\
The Saratov Region & 0.1562 & 0.1770 & 0.1815 & 0.2274 & 0.2672 & 0.1556 & 0,2043 & 0.2049 & 0.2151 \\
The Ulyanovsk Region & 0.0978 & 0.1046 & 0.1743 & 0.2285 & 0.1636 & 0.0935 & 0,1325 & 0.1515 & 0.1632 \\
\hline
\end{tabular}

*Author's calculations

Table 3 - Risk component value of the investment attractiveness of the Privolzhsky Federal District regions*

\begin{tabular}{|l|c|c|c|c|c|c|c|c|c|}
\hline & 2000 & 2005 & 2006 & 2007 & 2008 & 2009 & 2010 & 2011 & 2012 \\
The Republic of Bashkortostan & 0.2328 & 0.2318 & 0.2296 & 0.2567 & 0.2894 & 0.2781 & 0.2618 & 0.2615 & 0.2597 \\
The Republic of Marij El & 0.2494 & 0.2478 & 0.2478 & 0.2362 & 0.2214 & 0.2367 & 0.2365 & 0.2363 & 0.2465 \\
The Republic of Mordovia & 0.2185 & 0.2091 & 0.2165 & 0.2144 & 0.2613 & 0.2512 & 0.2417 & 0.2212 & 0.2371 \\
The Republic of Tatarstan & 0.1858 & 0.1808 & 0.1732 & 0.1721 & 0.1664 & 0.1893 & 0.1891 & 0.1805 & 0.1902 \\
The Udmurtian Republic & 0.2483 & 0.2365 & 0.2364 & 0.2374 & 0.2491 & 0.2496 & 0.2312 & 0.2311 & 0.2301 \\
The Chuvashi Republic & 0.2277 & 0.2312 & 0.2291 & 0.2291 & 0.2295 & 0.2316 & 0.2395 & 0.2281 & 0.228 \\
The Perm Territory & 0.2192 & 0.2185 & 0.2184 & 0.2113 & 0.2108 & 0.2164 & 0.2161 & 0.2134 & 0.193 \\
The Kirov Region & 0.2478 & 0.2471 & 0.2476 & 0.2482 & 0.2486 & 0.2501 & 0.2501 & 0.2487 & 0.201 \\
& 2000 & 2005 & 2006 & 2007 & 2008 & 2009 & 2010 & 2011 & 2012 \\
The Nizhni Novgorod Region & 0.2141 & 0.2415 & 0.2315 & 0.2201 & 0.2317 & 0.2323 & 0.2228 & 0.2157 & 0.232 \\
The Orenburg Region & 0.2842 & 0.2912 & 0.2912 & 0.2901 & 0.2874 & 0.2877 & 0.2871 & 0.2817 & 0.917 \\
The Penza Region & 0.2658 & 0.2516 & 0.2312 & 0.2365 & 0.2091 & 0.1864 & 0.1739 & 0.1731 & 0.1732 \\
The Samara Region & 0.2142 & 0.2216 & 0.2365 & 0.2287 & 0.2612 & 0.2454 & 0.2311 & 0.2301 & 0.2295 \\
The Saratov Region & 0.2191 & 0.2202 & 0.2205 & 0.2211 & 0.2231 & 0.2236 & 0.2205 & 0.2204 & 0.2196 \\
The Ulyanovsk Region & 0,2316 & 0.2311 & 0.2306 & 0.2485 & 0.2488 & 0.2512 & 0.2453 & 0.2427 & 0.2216 \\
\hline
\end{tabular}

* Author's calculations

Table 4 - Results of the assessment of the investment attractiveness of the Privolzhsky Federal District regions *

\begin{tabular}{|l|c|c|c|c|c|c|c|c|c|}
\hline & 2000 & 2005 & 2006 & 2007 & 2008 & 2009 & 2010 & 2011 & 2012 \\
The Republic of Bashkortostan & 0.1752 & 0.2411 & 0.2479 & 0.1288 & 0.1492 & 0.1210 & 0.1639 & 0.1757 & 0.2039 \\
The Republic of Marij El & 0.0477 & 0.2155 & 0.2210 & 0.1792 & 0.1065 & 0.1250 & 0.1515 & 0.1695 & 0.1707 \\
The Republic of Mordovia & 0.0546 & 0.1538 & 0.1562 & 0.1682 & 0.1008 & 0.0910 & 0.1022 & 0.1317 & 0.1553 \\
The Republic of Tatarstan & 0.1852 & 0.1553 & 0.1607 & 0.1718 & 0.1442 & 0.1217 & 0.1677 & 0.2487 & 0.2643 \\
The Udmurtian Republic & 0.0811 & 0.1515 & 0.1554 & 0.1995 & 0.1390 & 0.0910 & 0.1593 & 0.1529 & 0.1552 \\
The Chuvashi Republic & 0.0711 & 0.2017 & 0.2074 & 0.1986 & 0.1406 & 0.0999 & 0.0858 & 0.1583 & 0.1587 \\
The Perm Territory & 0.1626 & 0.1668 & 0.1710 & 0.2160 & 0.1837 & 0.1122 & 0.1724 & 0.1730 & 0.1835 \\
The Kirov Region & 0.0687 & 0.1630 & 0.1671 & 0.1444 & 0.1457 & 0.0933 & 0.1517 & 0.1461 & 0.1448 \\
The Nizhni Novgorod Region & 0.2083 & 0.1926 & 0.2002 & 0.1867 & 0.1466 & 0.1323 & 0.1226 & 0.1689 & 0.2044 \\
The Orenburg Region & 0.1687 & 0.3409 & 0.3496 & 0.2008 & 0.1154 & 0.1088 & 0.1040 & 0.2084 & 0.2052 \\
The Penza Region & 0.0678 & 0.1478 & 0.1557 & 0.1999 & 0.1136 & 0.0916 & 0.0819 & 0.1421 & 0.1476 \\
The Samara Region & 0.2411 & 0.2134 & 0.2147 & 0.1863 & 0.1355 & 0.1341 & 0.1883 & 0.1825 & 0.2294 \\
The Saratov Region & 0.1220 & 0.1380 & 0.1415 & 0.1771 & 0.2076 & 0.1208 & 0.1592 & 0.1598 & 0.1679 \\
The Ulyanovsk Region & 0.0751 & 0.0804 & 0.1341 & 0.1717 & 0.1229 & 0.0700 & 0.1000 & 0.1148 & 0.1270 \\
\hline
\end{tabular}

The analysis of obtained results allows to conclude that, despite the fluctuating changes in values of investment attractiveness, there has been an overall steady increase of investment attractiveness of regions. Moreover, the Republic of Tatarstan managed to keep the leading position in this group, the Samara region investment attractiveness has improved by more than $25 \%$, Nizhny Novgorod region (the change of investment attractiveness is $21 \%$ compared to the previous year) and the Republic of Bashkortostan (change of investment attractiveness is more than $16 \%$ ) managed to move into the group with the investment attractiveness above average. With a slight decrease of investment attractiveness the Orenburg region remained part in the group of leaders, took the second place to the Samara region. And although none one of the regions of the Privolzhsky Federal district got into the group with high investment attractiveness, the fruitful work of regions on the formation of favorable investment conditions is worth noting.

The Republic of Mordovia and Ulyanovsk region have been characterized by the most significant changes in the group of regions with the average investment attractiveness. These regions could not be moved from the group with an average investment attractiveness to the group with the investment attractiveness above average, however, they showed 
a progressive advance towards the improvement of investment attractiveness, the change in the index of investment attractiveness in these regions amounted to $17.92 \%$ and $10.63 \%$, respectively.

Such regions as the Saratov region, the Penza region, the Perm region managed to improve their investment attractiveness. Having kept their position in the group with average investment attractiveness, modification of investment terms have not been sufficient to improve their position among the regions of the Privolzhsky Federal district (the index of investment attractiveness rose by 3.9 to $6.2 \%$ ). The investment attractiveness of the Republic of Udmurtia, the Republic of Mari El and Chuvashia has remained practically the same.

Along with the Orenburg region, the Kirov region suffered the decrease of the investment attractiveness, however, the changes were minor, mainly associated with the regional market fluctuations.

There has been a slight decrease of investment attractiveness in the Orenburg and Kirov regions, which, however, managed to stay in the group of regions with the average investment attractiveness.

In general, it is worth mentioning that the regions of the Privolzhsky Federal district are characterized by average and above average investment attractiveness, demonstrating the opportunities of improving the climate for investments in the future. The comparative analysis of the results of investment attractiveness assessment, obtained during the study, along with the leading expert ratings agencies (Moody's, the Agency "Expert RA"), shows the consistency of the results obtained (Investment Climate in Constituents of Russian Federation in the Borders of the Privolzhsky Federal District: Issues and Ways of Resolving: report // pfo.ru).

\subsection{Projected volume of capital forming investments in the regions of PFD}

Based on the received dependence between the investment volumes and investment attractiveness and previous investment volumes using (Evaluation of investment attractiveness and prediction of investment volumes to the region, 2014) there have been predicted the volumes of investments in the regions of PFD in 2012-2020 (table. 5). Taking into consideration the economic trends made it possible to reflect investment attractiveness factors in the model and to assess their values in the future.

The difference of the projected values from the actual ones in the period of 2012-2013 is connected with the vigorous activity of the regional socio-economic systems on improving the investment environment and attracting not only foreign capital, but also the reorientating of domestic investment on regional markets.

According to the calculations made for the period of 2012-2020 (table 5) the investment volumes in the regions of Privolzhsky Federal District for this period will be characterized by an average annual growth rate of $4.1 \%$. The Republic of Tatarstan will still remain the obvious leader in terms of investment, despite a slight slowdown in the growth of investments in the region.

High amounts of investment are characteristic of the Nizhny Novgorod region, the Republic of Bashkortostan and Samara region, where the fluctuating dynamics of investment volumes does not affect the attraction of a significant volume of investment resources. This is due to the increased interest in the investment potential of the regions and the opportunity to successfully implement investment projects and programs. The improvement of the legislative acts, increase in social stability and reducing unemployment will work towards that as well. Moreover, a well-developed infrastructure of the investment market plays a special role, which in combination with ongoing activities for the development of the innovative market will promote active circulation of investments and, consequently, increase the investment attractiveness and investment volumes in these entities. Holding the summits of the SCO and BRICS in 2015 in the Republic of Bashkortostan has significantly enhanced its investment activities in the region and worked towards some redirection of domestic investments from other regions of the Privolzhsky Federal district.

High growth rates of investments are expected in the Republic of Bashkortostan (about $70 \%$ ), the Republic of Mari El (over $60 \%$ ), Samara region (50\%), Penza region (41.4\%), Kirov region (39.1\%), Nizhny Novgorod region (36.6\%) and the Ulyanovsk region (34.2\%), Orenburg region (33.7 \%).

The emphasis on the competitive advantages of these regions will allow them to generate attractive investment areas at the expense of their own natural resources. For example, in the Orenburg region, this is the tourist-recreational area (sector). For instance, the development of the territory of Sol-lletsk area, its climate and natural mud makes it possible to build up the resort of a global scale, comparable in characteristics with the salts and mud of the Dead sea.

It is expected that by 2020 the Republic of Mordovia and Perm region and the Udmurt Republic will ensure the inflow of investments in the regions exceeding the level of 2013 by almost a third. Such regions as the Chuvashi Republic, the Saratov region are characterized by relatively low growth rate but steady capital inflows.

In total, the Privolzhsky Federal district is expected to demonstrate positive dynamics of investments. It should be noted that in some regions a significant decline of investment volumes is projected by 2015 , on average, $7-8 \%$ in 
Saratov, Ulyanovsk and Kirov regions, in the Republic of Mordovia and Mari El Republic. For most regions of the Privolzhsky Federal district the year 2016 will be the year of the investment decline, except the Republic of Tatarstan and Nizhny Novgorod region. Maintaining a positive investment growth rate in these regions is associated primarily with the implementation of long-term investment projects and programs which form a significant part in the total investment flow in these regions.

After a significant increase in the investment sphere in 2017-2018 associated primarily with the active involvement of the results of intellectual activity in all sectors of the economy and the use of human capital, some deceleration is expected, and even some decline in the investment growth rate in 2019.

Stabilization of investment growth rate is projected by the end of 2020 , provided through investments in science and high-tech industry, entering new markets and increasing the number of free economic zones on the territory of the Privolzhsky Federal district.

Thus, the investment volumes in the economy of the regions of the Privolzhsky Federal district will grow. However, under existing conditions, their distribution and their rate will be characterized by chaotic outbursts. The expected investment will not be able to fully meet the needs of the regions. Considering that the forecast did not take into account changes in the investment attractiveness of regions, the aim of regions authorities, using the results obtained, is to modify the factors of investment attractiveness, ensure the most effective use of available resources and increase the inflow of investments.

Table 5 - Forecasting the Volumes of Investment in the Regions of Privolzhsky Federal District, mln RUR*

\begin{tabular}{|c|c|c|c|c|c|c|c|c|c|c|}
\hline & & 2012 & 2013 & 2014 & 2015 & 2016 & 2017 & 2018 & 2019 & 2020 \\
\hline \multirow{2}{*}{$\begin{array}{l}\text { The Republic of } \\
\text { Bashkortostan }\end{array}$} & $\begin{array}{l}\text { Lower bound of } \\
\text { forecast }\end{array}$ & \multirow{2}{*}{$\begin{array}{c}211928.25 \\
(233683)\end{array}$} & \multirow{2}{*}{$\begin{array}{c}203523.35 \\
(266233)\end{array}$} & 299184.14 & 288359.29 & 274882.38 & 314004.09 & 333577.61 & 287414.88 & 332219.13 \\
\hline & $\begin{array}{l}\text { Upper bound of } \\
\text { forecast }\end{array}$ & & & 324116.16 & 340788.25 & 332519.01 & 350235.33 & 375274.81 & 335317.36 & 389170.98 \\
\hline \multirow{2}{*}{ The Republic of Marij El } & $\begin{array}{l}\text { Lower bound of } \\
\text { forecast }\end{array}$ & \multirow{2}{*}{$\begin{array}{c}28805.71 \\
(31656)\end{array}$} & \multirow{2}{*}{$\begin{array}{c}30177.99 \\
(45126)\end{array}$} & 42601.377 & 39784.94 & 37010.784 & 40504.88 & 42077.111 & 41737.085 & 44995.72 \\
\hline & $\begin{array}{l}\text { Upper bound of } \\
\text { forecast }\end{array}$ & & & 45878.406 & 41927.206 & 40711.862 & 43620.64 & 45505.616 & 45589.739 & 48209.7 \\
\hline \multirow{2}{*}{$\begin{array}{l}\text { The Republic of } \\
\text { Mordovia }\end{array}$} & $\begin{array}{l}\text { Lower bound of } \\
\text { forecast }\end{array}$ & \multirow{2}{*}{$\begin{array}{c}48044.63 \\
(49825)\end{array}$} & \multirow{2}{*}{$\begin{array}{c}54946.08 \\
(53699)\end{array}$} & 55407.07 & 54636.996 & 52528.99 & 56901.222 & 59408.843 & 60525.602 & 61250.249 \\
\hline & $\begin{array}{l}\text { Upper bound of } \\
\text { forecast }\end{array}$ & & & 60947.777 & 59143.14 & 57781.889 & 59610.804 & 62237.835 & 63463.738 & 63606.028 \\
\hline \multirow{2}{*}{$\begin{array}{l}\text { The Republic of } \\
\text { Tatarstan }\end{array}$} & $\begin{array}{l}\text { Lower bound of } \\
\text { forecast }\end{array}$ & \multirow{2}{*}{$\begin{array}{c}444684.30 \\
(470751)\end{array}$} & \multirow{2}{*}{$\begin{array}{c}385401.67 \\
(520228)\end{array}$} & 503604.45 & 478102.38 & 492448.2 & 511546.39 & 496220.67 & $50952 ., 31$ & 531529.48 \\
\hline & $\begin{array}{l}\text { Upper bound of } \\
\text { forecast }\end{array}$ & & & 542343.26 & 537865.18 & 540223.03 & 553539.01 & 536894.49 & 539243.38 & 561295.13 \\
\hline \multirow{2}{*}{ The Udmurtian Republic } & $\begin{array}{l}\text { Lower bound of } \\
\text { forecast }\end{array}$ & \multirow{2}{*}{$\begin{array}{c}69857.62 \\
(64221)\end{array}$} & \multirow{2}{*}{$\begin{array}{c}80811.37 \\
(71820)\end{array}$} & 73314.396 & 74745.081 & 71850.675 & 77438.805 & 79577.862 & 82748.952 & 85536.135 \\
\hline & $\begin{array}{l}\text { Upper bound of } \\
\text { forecast }\end{array}$ & & & 79831.231 & 81389.088 & 77258.79 & 81430.496 & 83766.17 & 87104.16 & 89900.223 \\
\hline \multirow{2}{*}{ The Chuvashi Republic } & $\begin{array}{l}\text { Lower bound of } \\
\text { forecast }\end{array}$ & \multirow{2}{*}{$\begin{array}{c}56957.93 \\
(65255)\end{array}$} & \multirow{2}{*}{$\begin{array}{c}63446.46 \\
(59139)\end{array}$} & 50403.79 & 59189.599 & 54521.264 & 56743.289 & 67986.96 & 67168.3 & 66062.22 \\
\hline & $\begin{array}{l}\text { Upper bound of } \\
\text { forecast }\end{array}$ & & & 55444.169 & 63417.428 & 62310.016 & 63418.97 & 72236.145 & 70526.715 & 72668.442 \\
\hline \multirow{2}{*}{ The Perm Territory } & $\begin{array}{l}\text { Lower bound of } \\
\text { forecast }\end{array}$ & \multirow{2}{*}{$\begin{array}{c}144545.75 \\
(162241)\end{array}$} & \multirow{2}{*}{$\begin{array}{c}145232.59 \\
(188719)\end{array}$} & 159081.24 & 181939.15 & 151086.53 & 183367.52 & 212584.14 & 179977.35 & 181326.73 \\
\hline & $\begin{array}{l}\text { Upper bound of } \\
\text { forecast }\end{array}$ & & & 168921.32 & 193193.11 & 160432.09 & 194709.84 & 225733.68 & 191109.97 & 192542.81 \\
\hline \multirow{2}{*}{ The Kirov Region } & $\begin{array}{l}\text { Lower bound of } \\
\text { forecast }\end{array}$ & \multirow{2}{*}{$\begin{array}{c}39463.57 \\
(50545)\end{array}$} & \multirow{2}{*}{$\begin{array}{c}40223.98 \\
(56836)\end{array}$} & 50156.307 & 46934.076 & 47331.896 & 47863 & 47883.574 & 49459.453 & 49525.854 \\
\hline & $\begin{array}{l}\text { Upper bound of } \\
\text { forecast }\end{array}$ & & & 61059.852 & 57137.136 & 57621.438 & 58268 & 58293.046 & 60211.508 & 60292.344 \\
\hline \multirow{2}{*}{$\begin{array}{l}\text { The Nizhni Novgorod } \\
\text { Region }\end{array}$} & $\begin{array}{l}\text { Lower bound of } \\
\text { forecast }\end{array}$ & \multirow{2}{*}{$\begin{array}{c}242134.73 \\
(257454)\end{array}$} & \multirow{2}{*}{$\begin{array}{c}262333.56 \\
(272212)\end{array}$} & 250010 & 261098.69 & 273084.34 & 278739.38 & 295233.83 & 280188.24 & 324524.29 \\
\hline & $\begin{array}{l}\text { Upper bound of } \\
\text { forecast }\end{array}$ & & & 270844.17 & 295911.85 & 305211.91 & 300601.29 & 329967.22 & 310404.62 & 351567.98 \\
\hline \multirow{2}{*}{ The Orenburg Region } & $\begin{array}{l}\text { Lower bound of } \\
\text { forecast }\end{array}$ & \multirow{2}{*}{$\begin{array}{c}120310.37 \\
(151250)\end{array}$} & \multirow{2}{*}{$\begin{array}{c}125416.39 \\
(152573)\end{array}$} & 155156.62 & 153369.01 & 126739.18 & 154431 & 179976.97 & 151529.85 & 152855.08 \\
\hline & $\begin{array}{l}\text { Upper bound of } \\
\text { forecast }\end{array}$ & & & 169261.76 & 169513.11 & 140080.14 & 170686.9 & 198921.91 & 167480.37 & 168945.08 \\
\hline The Penza Region & $\begin{array}{l}\text { Lower bound of } \\
\text { forecast }\end{array}$ & $\begin{array}{c}58470.22 \\
(72343) \\
\end{array}$ & $\begin{array}{c}66271.66 \\
(80775) \\
\end{array}$ & 74069.721 & 69957.128 & 70270.915 & 72555.296 & 75945.331 & 78924.582 & 79093.256 \\
\hline
\end{tabular}




\begin{tabular}{|c|c|c|c|c|c|c|c|c|c|c|}
\hline & $\begin{array}{l}\text { Upper bound of } \\
\text { forecast }\end{array}$ & & & 80803.332 & 82302.504 & 76659.18 & 79151.232 & 82849.452 & 86099.544 & 86283.552 \\
\hline \multirow{2}{*}{ The Samara Region } & $\begin{array}{l}\text { Lower bound of } \\
\text { forecast }\end{array}$ & \multirow{2}{*}{$\begin{array}{c}197792.44 \\
(213022)\end{array}$} & \multirow{2}{*}{$\begin{array}{c}172569.86 \\
(262326)\end{array}$} & 250788.68 & 286722.46 & 237747.74 & 288882.8 & 335427.59 & 283515.35 & 285745.19 \\
\hline & $\begin{array}{l}\text { Upper bound of } \\
\text { forecast }\end{array}$ & & & 270080.12 & 308778.04 & 256036.03 & 311104.56 & 361229.71 & 305324.22 & 307725.59 \\
\hline \multirow{2}{*}{ The Saratov Region } & $\begin{array}{l}\text { Lower bound of } \\
\text { forecast }\end{array}$ & \multirow{2}{*}{$\begin{array}{c}107555.65 \\
(117646)\end{array}$} & \multirow{2}{*}{$\begin{array}{c}106991.83 \\
(122181)\end{array}$} & 115895.86 & 104422.88 & 95452.852 & 114335.02 & 116609.67 & 116725.61 & 121128.06 \\
\hline & $\begin{array}{l}\text { Upper bound of } \\
\text { forecast }\end{array}$ & & & 128773.18 & 113915.87 & 104130.38 & 124729.12 & 127210.55 & 127337.03 & 132139.7 \\
\hline \multirow{2}{*}{ The Ulyanovsk Region } & $\begin{array}{l}\text { Lower bound of } \\
\text { forecast }\end{array}$ & \multirow{2}{*}{$\begin{array}{c}60538.69 \\
(72985)\end{array}$} & \multirow{2}{*}{$\begin{array}{c}63614.27 \\
(76244)\end{array}$} & 73880.121 & 66318.603 & 72169.561 & 66589.543 & 74405.713 & 77577.666 & 77864.66 \\
\hline & $\begin{array}{l}\text { Upper bound of } \\
\text { forecast }\end{array}$ & & & 77398.22 & 72085.44 & 78445.18 & 72379.94 & 80875.78 & 84323.55 & 84635.5 \\
\hline
\end{tabular}

* Author's calculations

Reported by the data of 2012-2013 there are presented the results of point prediction, in brackets - the fact sheet is given.

\section{Conclusions}

The suggested approaches and models developed on their basis allow us:

- to link the received values of investment attractiveness with financial calculations of investors and regional authorities of development, since this indicator characterizes the profitability of invested funds with allowances made for probable losses;

- to apply the obtained results to compare regions, not only within Russia, but also outside its borders;

- $\quad$ to predict future levels of investments; to develop a mechanism of the investment inflow management, using the multivariance of selection (choice);

- to correct and efficiently allocate the centralized investment flows taking into account the priorities of economic development of the socio-economic system;

- to specify the main directions of activities of investment management entities controlling economic and social systems;

- to determine the directions and forms of capital allocation based on the assessment of investment attractiveness of socio-economic systems.

This gives the opportunity to identify differences in regional development, to identify the factors that determine them, and to develop a mechanism of influence on these factors that contribute to achieving the desired level of development of the region at minimum cost. Thus, the main difference and advantage of the suggested approach to the assessment of investment attractiveness is not only to define the position of the region among the set of regions, but also to use the results of the assessment for management decision making.

Since by its nature the analyzed indicator of investment attractiveness reflects the risk-based profitability of investments, the results can be used to analyze the current state of the regions, or to compare regions with each other. To be able not only to monitor but also regulate the flow of investments into the region, it is necessary to build a formalized dependence of the investment volume on the index of investment attractiveness of the region.

The inclusion of the index of investment attractiveness (considering various factors) in the forecasting model of investments volume gives the possibility to adjust the volumes of investments in a variety of ways and methods in various combinations with the results of regulation. The variety of options for authorities to manage economic system widens the range of use of the model and therefore allows to achieve the desired result at minimum cost.

The evaluation of expected volume of investments in the regions can be used to forecast the development of the economic system, and, above all, to predict economic growth. This applied aspect of the problem becomes especially important at critical stages of development, for example, at economic recovery (overcoming the crisis). Another important practical result of the calculation of expected volume of investments is determining relative volumes of shortage or excess of investments and therefore developing strategies in respect of possible import and export. It appears that these aspects of calculation of expected volume of investments in the practice of macroeconomic forecasting and state regulation are not enough worked over and need further study.

The analysis shows that the use of standard forecasting procedures allows to obtain results of high quality. Thus there is a need to improve the algorithm for determining and predicting the perturbations of the investment process which will improve the accuracy of calculations, and identifying criteria for optimal growth of the investments to ensure the 
effective functioning of the economic system.

Applied calculations of expected volume of investments in the regions of the Russian Federation indicate that even under favorable conditions it will not be possible to fully meet the demand of the economy for investment resources. Therefore, an important task of authorities is to change the state of the investment climate for increasing the inflow of capital forming investments and to fully meet the needs of the society.

\section{References}

Valinurova, L.S. (2002). Upravlenie investicionnym processom v jekonomicheskih sistemah. I L.S. Valinurova. M.: Izdatel'stvo «Paleotip», pp. 324.

Valinurova, L.S., Kazakova O.B. (2005). Upravlenie investicionnoj dejatel'nost'ju: uchebnik. /L.S. Valinurova, O.B. Kazakova. M.: KNORUS. pp. 384.

Goncharenko, L.P., Filin S.A., Jakushev A.Zh., Akulinin V.F. \& Kuz'mishhev D.A. (2013) Realizacija investicionnogo potenciala regionov posredstvom povyshenija investicionnoj privlekatel'nosti i vovlechenija biznesa $v$ investicionnyj process / L.P.Goncharenko, S.A.Filin, A.Zh.Jakushev, V.F.Akulinin // Regional'naja jekonomika: teorija i praktika. №. 28. pp. 2-11.

Goncharov, A.N. (2012) Investicionnaja privlekatel'nost' kak faktor razvitija sel'skih territorij/ A.N. Goncharov // FJeS: Finansy. Jekonomika. Strategija. №. 4.

Investicionnyj klimat v sub\#ektah Rossijskoj Federacii, nahodjashhihsja v predelah Privolzhskogo federal'nogo okruga: problemy i puti reshenija: doklad // pfo.ru

Kardash, V.A. (1998) Osnovy sistemnyh issledovanij i matematicheskogo modelirovanija. I V. A. Kardash. Kislovodsk: KIJeP.

Litvinova, V.V. (2013) Investicionnaja privlekatel'nost' i investicionnyj klimat regiona. / V. V. Litvinova. M.: Finuniversitet. 116.

Mjakshin, V.N. (2014) Primenenie metodologii sbalansirovannoj ocenki investicionnoj privlekatel'nosti dlja sovershenstvovanija regional'noj investicionnoj politiki / V.N. Mjakshin // Regional'naja jekonomika: teorija i praktika. №. 12. pp. 23-33.

Ocenka investicionnoj privlekatel'nosti i prognozirovanie ob\#emov investicij v region // Sv-vo o gos.reg.progr.dlja JeVM №. 2014661093, Valinurova L.S., Kazakova O.B., avtory i pravoobladatel' Valinurova L.S., Kazakova O.B. (RU)/ - No. 2014617899: zajavl. 07.08.2014 4: Zaregistrirovano v Reestre programm dlja JeVM 23.110.2014

Rossijskij statisticheskij ezhegodnik (2013): Stat.sb./Rosstat. - R 76 M. pp.786.

Rjahovskij, D.I, Akulova N.G. \& Babanov A.V. (2014) Razvitie mehanizma upravlenija investicionnoj privlekatel'nost'ju regiona. / D.I. Rjahovskij, N.G.Akulova, A.V.Babanov. M.: In-t jekonomiki i antikrizisnogo upravlenija. pp. 189.

Kemeny, Thomas (2010). Does Foreign Direct Investment Drive Technological Upgrading? World Development, Volume 38, Issue 11, November: 1543-1554.

Fankhauser, Samuel \& Lavric, Lucia (2003). The investment climate for climate investment: Joint Implementation in transition countries. Climate Policy, Volume 3, Issue 4, December: 417-434. 